\title{
YHWH, the God of new beginnings: Micah's testimony
}

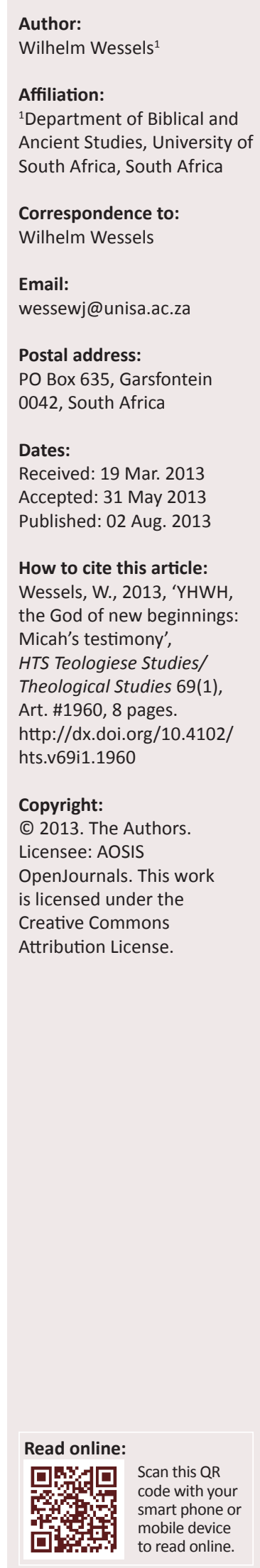

The book of Micah is known for its judgement oracles against the leadership structures in the Southern Kingdom, Judah. Besides the judgement oracles, however, the book also contains oracles of salvation. Scholars have noted and commented on this interruption of predominant judgement oracles by oracles of salvation. The composition of the book has been scrutinised, with many scholars suggesting that the salvation oracles were inserted later to soften the harsh, condemning nature of the book. For the purposes of this article I would like to propose a theological reading of the juxtaposition of Micah 3:12 and 4:1, two passages containing judgement and salvation oracles respectively. The solutions offered to explain the drastic contrast between these two passages have to a great extent reached an impasse. However, from a theological perspective, I argue that these two radically contradictory messages are a reflection of the very nature of YHWH's interaction with his people. Micah 3:12 reflects a point in history where $\mathrm{YHWH}$ has had enough of morally corrupt leaders and people, and announces that he is bringing matters to a painful end. However, YHWH is also the God of new beginnings. He states in Micah 4:1ff. that there will come a day when things will change for the better for the people of Judah and that a time of restoration will come for his people. His desire remains to be their God and to restore them to be his people. The article seeks to show that this example, which reflects YHWH as the God of new beginnings, is not an isolated example in the prophetic literature, but consistent with YHWH's nature.

\section{Introduction}

The book of Micah is known for its judgement oracles against the leadership structures in the Southern Kingdom, Judah. Besides the judgement oracles, the book also contains oracles of salvation. It is significant that the oracles of doom that predominate in the book are interrupted by oracles of salvation, raising questions about the composition of the book. To solve this issue, many scholars have suggested that the salvation oracles were inserted later to soften the harsh, condemning nature of the book.

The article investigates the juxtaposition of oracles of judgement and salvation in the book of Micah. It begins with a brief overview of how the composition of this book is regarded by scholars and the solutions they propose. This will be followed by taking one example from the Micah text to show the complexity of the problem and to suggest another way of approaching the issue at stake. The texts chosen for this exercise are Micah 3:9-12 and 4:1-5. These two passages will be analysed thoroughly. At the end of the article, other, similar occurrences of judgement oracles alternating with oracles of salvation are referred to, to test the validity of the proposed approach to this phenomenon.

\section{Composition and approaches to the book of Micah: A concise overview}

Many scholars have over a long period of time undertaken critical research on the book of Micah. Valuable insights have been gained, but many unsolved questions remain. The composition of the book has received much attention. Several proposals have been offered to address questions such as: what material can be regarded as authentic to Micah; what sections were added; what redaction processes the book underwent and how the book is structured (cf. Wolff 1990:17-27; also Anderson \& Freedman 2000:16-20; Wagenaar 2001:6-15; Waltke 2007a:13-16).

Unfortunately, the debate has reached a general stalemate; the solutions that are now offered, are more a matter of preference and emphasis.

\section{Composition of the book of Micah}

Very little is actually known of the origin and compilation of the book of Micah. Research indicates that the text went through a process of growth and rearrangement throughout its development. 
Apparently, this process was conducted by circles who kept the prophetic tradition alive and who added to the text what could be spiritually associated with the person of Micah and his proclamation. The process took place over an extended period of time. What is certain is that this text was associated with Micah all along in biblical tradition, as shown by Jeremiah 26:18, 19.

The above-mentioned issues are not the only ones contributing to the problematic nature of this book. McKane (1998) discusses the many textual issues of Micah in his commentary in detail. In some instances it is difficult to understand and translate the Hebrew text. The authenticity of certain passages in Micah is also a concern. Most scholars regard chapters 1-3, with the exception of 2:12-13, to be from Micah. However, there are differences of opinion when it comes to chapters 4-7. The strong contrast between 3:12 ('Jerusalem shall become a heap of ruins ...') and what follows in chapters 4 and 5 about the restoration and importance of Zion and salvation for Israel makes it difficult for some to accept that Micah could be responsible for both parts. The collection of the material and arrangement of the text in its final form do not necessarily deny that the oracles can be related to Micah. Furthermore, if one allows for a process of application and actualisation of the Micah material, as seems to be the case, then it is unnecessary to deny Micah's association with some of the positive oracles.

Strong arguments are also presented to deny Micah's authorship of chapters 6-7 (cf. Andersen \& Freedman 2000:18-20). These chapters are regarded as deriving from a northern Israelite prophet who lived earlier than Micah (Van der Woude 1976:195-199). Arguments in favour of this view are based on historical and geographical data (cf. 6:5; 6:16, 7:14), traditions of the Northern Kingdom (cf. 6:4; 7:15), theological fundamentals such as the covenant and election, and linguistic arguments. Although the general arguments against the authorship of Micah for chapters 6-7 seem strong, each subsection of these chapters, as well as of chapters 4-5 should be considered individually.

On the one hand, the history of research on Micah leaves the impression of excellence and thoroughness. On the other hand, it is evident that there are as many viewpoints as there are researchers and thus no really conclusive answers. This situation has been caused by the historical and interpretational difficulties in this book, the limited available information and perhaps most of all, the ineffectiveness of the tools we use in research (cf. Mason 1991:39-40).

\section{Approaches to the book of Micah}

Four approaches to the book of Micah will briefly be overviewed. These are literary criticism, form and redaction criticism, literary-thematic approaches and rhetorical criticism. Over the years much work has been done through literary criticism. ${ }^{1}$ The main concern was to determine what could be regarded as authentic to Micah, which sections were

1.Cf. Mason (1991:28-32) for a broader discussion of views of scholars such as $\mathrm{H}$ Ewald (1840,1867), B. Stade (1881), J.M.P. Smith (1911), D.W. Thomas (1962) and J.L. Mays (1979). Cf. also the work of Hagstrom (1988) on the coherence of the book of Micah. A useful overview of trends in Micah studies is offered by Jacobs book of Micah. A
(2006:293-329). secondary and who the individuals responsible for the latter were. Decisions on this were made by applying literary, historical and theological criteria. As mentioned before, most scholars would agree that chapters 1-3 stem from Micah, whilst others would argue that more than these three chapters were originally written by Micah. Waltke (1988:149) regards all the oracles as authentic, whereas Allen (1976:251) doubts the authenticity of 4:1-4, 4:6-8 and 7:8-20. Van der Woude 1976:10-11 views chapters 1-5 as original, but assigns chapters 6-7 to a prophet a little earlier than Micah, which he calls Deutero-Micah. It is primarily the contrast between the oracles of hope vis-à-vis the strongly judgemental nature of Micah's proclamation that has caused most scholars to regard these oracles as exilic or even post-exilic.

Another approach focuses on the form of smaller units and poses questions as to who was responsible for the present form of the book and the reasons for this. Although the focus shifted somewhat from the previous approach, the form and redaction critics built on the results of the literary critics. An important result of this focus on the form and on those responsible for the present form of the Micah text, is that the historical users (the community) of the material and the purpose of the application of the material receive attention. Mason (1991:35-39) discusses the views of Gunkel, Reicke, Jeremias, Willi-Plein, Lescow and Renaud. Renaud regarded the reading of the text in the light of the Samaritan schism, probably in the 4th century BCE, as a final stage. Another influential scholar, Wolff (1990), makes extensive use of a form-critical and redaction-historical methodology in his commentary, whilst Wagenaar (2001) has also contributed to the debate on compositional and redaction matters of the book Micah.

Despite great differences amongst those who emphasise form and function, these authors have succeeded in arguing a strong case for the dynamic process of growth and the reapplication of the text under different circumstances. This also implies that the present form and arrangement of the text are significant.

Two more approaches need attention. The first is a literary-thematic approach which takes the literary and structural aspects of the text, as well as key concepts, into consideration. An example of this approach is the research of Cuffey (1987:301-305), who finds coherence in structural linkage, in the theme of the book, in the internal linkage and in the perspective of Micah. The key concept is 'remnant', which appears in four strategic places in the book. Cuffey therefore works with a four-part division of the book: 1:2$2: 13 ; 3: 1-4: 8 ; 4: 9-5: 14$ and $6: 1-7: 20$. Each of these sections consists of a negative part followed by a positive section which contains the idea of a remnant (cf. 2:12-13; 4:1-8; 5:1$14 ; 7: 7-20)$. A number of scholars have either worked with a two-part division of chapters 1-5 and 6-7 (Mays 1976:3), or with a three-part division: chapters 1-2, 3-5 and 6-7 (e.g. Allen 1976:260-261; Waltke 2007a:13-15) or 1-3, 4-5 and 6-7 (e.g. Andersen \& Freedman 2000:7-14; Brueggemann 2003:234-235). Besides stressing the coherence of the book, 
Cuffey also posits a possible exilic date for activity regarding matters of redaction. According to him, this is the most likely time in which the idea of the remnant would be significant (Cuffey 1987:377-380).

The last approach to be overviewed is that of rhetorical criticism. In a study in which a form of rhetorical criticism is applied, Shaw (1993) works with the presupposition that the book of Micah consists of several persuasive prophetic discourses. The objective is to warn and to change the views and the attitudes of the prophet's audience by pointing out the consequences of people's deeds. Interest is shown in the 'rhetorical situation' which would help to determine a possible historical situation in which the specific discourse was delivered. It is acknowledged that we have no account of the situation which gave rise to each of the discourses, but that one must attempt to reconstruct possible situations. The following six discourses are distinguished in the book of Micah: 1:2-16; 2:1-13; 3:1-4:8; 4:9-5:14; 6:1-7:7 and 7:8-20. This proposed way of dealing with the Micah text, as well as the previous approach, seems workable. Proposals differ because the advocates of such proposals approach the biblical texts from a particular view which they regard as important, be it structural and thematic aspects or emphasis on rhetorical matters as illustrated above.

Scholars have to realise that in spite of all their sound theories and explanations, human limitations just will not allow us to grasp the entire picture. Hillers (1984:3-4) refers to two factors, namely 'loss' and 'chance', which he regards as significant. His view is that researchers do not allow for these two factors when they form theories on the text of Micah. In all probability we have a far too simple view of the entire growth and fixation of the text. Scholars should be cautious not to downgrade some sections in Micah too easily as secondary additions to the book. It is possible that Micah or even any of the other prophets could have proclaimed both oracles of doom and oracles of salvation. It depends on the circumstances and the context in which an oracle was relevant. It is also true that other books of the Old Testament show evidence of growth and editorial processes.

With this brief overview in mind, we need to look at Micah 3:9-12 and $4: 1-5$ as an example of the difficulty scholars face in making sense of the Micah text. It is clear from the overview that the placement of salvation oracles between oracles of doom was regarded as problematic. The case of 3:9-12 and 4:1-5 is even more problematic, because although both concern Zion, the content seems contradictory. The two textual units will first be discussed separately and then as part of the problem of juxtaposing oracles of doom and salvation that seem to contradict one another.

\section{Exposition of Micah 3:9-12}

Micah 3 is a judgement oracle consisting of 12 verses which can be divided into three subsections, namely $3: 1-4,5-8$ and 9-12. This article is primarily interested in 3:9-12, but this passage should be understood within the context of chapter 3 as well as the rest of the book. Some scholars regard chapter
3 as a response to 2:6-11 (Jacobs 2001:84-85; Van der Woude 1976:10-11, 61-64). In 3:1 the leaders and rulers of Jacob and Israel are addressed, in 3:5 the prophets and other religious leaders and in 3:9 again the leaders and rulers of Jacob and Israel as well as the judges, priests and prophets.

In Micah 3:1-4 the political and civil leaders are condemned for not doing what is right and just. This is done by using atrocious language and imagery. The leaders referred to are rebuked for exploiting and devouring ordinary people. It is said that, as a result of this, YHWH will refuse to listen to them. This is followed in 3:5-8 by a section that condemns the practices of mainly the prophets, but also the seers, diviners and soothsayers. The prophets ask people to 'put food in their mouths' and then proclaim false peace to people. As a result YHWH will take away their very existence as prophets, because they will not receive any vision or revelation from him. YHWH will again refuse to answer these religious functionaries (cf. Grabbe 1995 on priests, prophets and diviners). All the other religious functionaries will be disgraced and shamed because of their falseness. The prophet himself, however, will not hesitate to proclaim the truth to Jacob and Israel. This will be the case because the prophet Micah claims to be filled with the power, with the Spirit of YHWH, with justice and might (Wessels 2009:33-47).

This brings Micah 3:9-12 into focus. This passage is introduced by a call to the leaders of Jacob and Israel to listen attentively to a word of judgement aimed at them, similar to the one in 3:1. They are once again, as in verse 1, blamed for the abuse of justice. The political leaders are not only indicted for despising and distorting justice, but also for building Zion with bloodshed and Jerusalem with wickedness. In verse 11 the accusation against the leaders is broadened to include the judges, priests and some prophets. Those who serve as judges take bribes, the priests request payment for their teaching and the prophets make predictions for money. What is described here is the moral depravity of the Judean society, their leaders taking the lead in acting unjustly. To illustrate his amazement with the arrogance of these leaders, the prophet states that in spite of these atrocities and unjust behaviour, the leaders still expect $\mathrm{YHWH}$ to come to their aid. Even more, they declare 'Is not the Lord among us? No disaster will come upon us.'

On the call to pay attention and the indictment against these leaders a verdict follows. Verse 12 is introduced with lakken [therefore] followed by the verdict. These leaders are to be blamed for the judgement to follow: 'Zion will be ploughed like a field, Jerusalem will become a heap of rubble, the temple hill a mound overgrown with thickets' (New International Version [NIV]). A vivid picture of total destruction is painted here to emphasise the severity of the verdict. However, the religious and emotional consequences of this proclamation of judgement are more important than the physical destruction depicted here. The foundation on which their security is built will be removed and destroyed. Zion will be ploughed like a field, Jerusalem will be uninhabitable and more than that, the temple where $\mathrm{YHWH}$ is present will be inaccessible to the 
people. YHWH will not listen to the political and civil leaders or answer them, he will give no visions and revelations to the religious functionaries and he will retract his presence and help from his people. They have become arrogant and selfreliant and have a false sense of security.

Micah acted during the reigns of Ahaz (735-715 BCE) and Hezekiah (715-687 BCE). Micah 3 should possibly also be read against the background of a time of incisive changes in the society. Some people gained positions of power which they misused to exploit others. Poor and powerless people were exploited, resulting in the loss of land. Mention is also made of people building Jerusalem with the blood of people (cf. 3:10). Power was in the hands of the political leaders who were also the chief advocates of the Zion ideology. They used this ideology to protect and strengthen their entrenched positions. These leaders found support from some of the prophets and other religious functionaries in Judean society who assisted them to remain in power. Therefore, they deserve YHWH's judgement.

\section{Exposition of Micah 4:1-5}

In contrast to the announcement of judgement in 3:12, Micah 4:1 clearly sets a new tone with the introduction of an oracle of salvation. The various passages collected in Micah chapters 4 and 5 are regarded as salvation prophecies. The juxtaposition of judgement and salvation has led to many studies. To a great extent, the discussions of these two passages next to each other have reached an impasse. It should be acknowledged that many of the oracles in Micah 4-5 are contradictory to the judgement oracles collected in Micah 1-3. However, 3:9-12 and 4:1-5 are not only juxtaposed, but 4:1-5 seem to counter the judgement announced in 3:9-12.

The oracles in chapters 4 and 5 are divergent, even contradictory in content. The connecting elements seem to be Zion or Jerusalem, the people of Jacob and the nations. On the one hand, one is confronted with imagery of restoration and peace $(4: 1-4,6-7 ; 5: 2-5 a)$, on the other hand with images of aggression and retaliation $(4: 13 ; 5: 5 b-6 ; 8-9)$.

As mentioned, many viewpoints exist which attempt to explain both the juxtaposition of 3:12 with $4: 1$ and the diverse nature of the material collected in Micah 4 and 5 (see the detailed discussions offered by Mason 1991:31-33; Shaw 1993:131-139; Hagstrom 1988:72-84; McKane 1998:119). Two opposing views argue for the coherence of these salvation oracles, or treat them as a divergent collection of salvation oracles. Some would date the divergent collection of oracles in the time of Micah in the 8th century, whilst others regard some oracles to be exilic and even post-exilic. The ideas of an exile (cf. 4:6-7) and restoration (cf. 4:6-7) and the explicit mention of Babylon in verse 10 support the notion of an exilic or post-exilic dating for most of these oracles. The tendency to refer to the universal role of the nations and the almost utopian view of Zion seem to fit the world of Deutero-Isaiah better and would rather support an exilic dating.
A third possibility to consider is to regard chapters 4 and 5 as a dispute between the prophet and his opponents, a pattern already present in chapter 2. This view was thoroughly argued by Van der Woude in his 1976 commentary, but his presentation of the dialogue between the opposing parties gives the last word to the 'false prophets' (cf. 5:7-14), making it less convincing. Alfaro (1989:42-61) has argued along similar lines, but by structuring the dispute slightly differently, he offers a more likely option. Be that as it may, it is difficult to reconstruct the composition of the book of Micah with any form of certainty. One should also allow for the effect of speech utilised by prophets to provoke the imagination of the people they wished to influence, challenge and change, or give hope for the future (cf. Brueggemann 1994:91-92). A prophetic text such as Micah calls for imaginative and creative exposition to allow for all interpretational facets. Perhaps it is reasonable to assume that at some stage oracles proclaimed by Micah and others closely related to his oracles were put together to form the book of Micah.

There is a close resemblance between Isaiah 2:2-4 and Micah 4:1-4. The obvious question is what accounts for such similarity (cf. Wildberger 1972:75-80 for a thorough discussion of the two passages; cf. also McKane 1998:119-124; Andersen \& Freedman 2000:413-427; Waltke 2007a:191-192).

It is possible that both Isaiah and Micah used an existing cultic oracle which originated independently of either of them. Shaw (1993:107) views Micah 4:1-5 as an oracle that reflects a liturgical style that was familiar to Micah's audience, quoted as a rhetorical device. It is important to notice that the oracle in 4:1-4 links thematically with the previous passage in chapter 3 with its focus on Zion.

Micah 4:1 is introduced by means of a temporal expression (cf. Is 2:2; Jr 49:39) alluding to days that have passed. In this context it could refer to the events in 3:12 which describe the fate of Zion (Troxel 2012:65). The reference 'in days to come' implies a future time. Waltke (2007a:192-193) has engaged several scholars on how this time reference should be interpreted and concludes that it does not have an eschatological meaning, but refers to the future. He says:

The syntagma designates a future that is not presently discernible, the hiddenness of the future things ... it points to a new epoch, which, though it lies in the hidden future, comprehensively alters time and is the goal or outcome toward which an event is striving. (Waltke 2007a:193)

Verse 1 therefore announces that in future the temple mount will become the focus of attention, portrayed as the highest amongst the mountains, metaphorically indicating its importance. It will be so prominent that people will stream to it (cf. Rogerson 2009:39-41). Mountains and heights had special significance for people in ancient times. Keel (1978:113) mentions the following three theological notions temple mountains had in ancient Near Eastern religions: A symbol of a god's victory over chaos; an access to heaven; and a symbol of a god's presence (his house on a mountain on earth). This third meaning ties in with Israel's and Judah's 
understanding of the significance of the temple in Jerusalem. It is all about YHWH's presence amongst his people.

It is clear from this scenic description that the prophet (redactor) wants to stir the imagination of people through the effective use of images. Zion has symbolic significance and is depicted as the true place of worship (Waltke 2007:194). The Zion of the future will be different from the previous one and will have a place in the international arena. Zion will symbolise YHWH's rule that extends over the whole world. In the days to come, the reference to the temple mount being higher than those of the surrounding nations, will imply that Israel's religion is universal and superior.

The emphasis in verse 2 is on the verb hlk [to go], repeated three times. It should be understood literally in the first two instances, indicating the movement of the nations to the temple mount. The third use is metaphorically intended in the sense of living according to YHWH's instructions. The nations are quoted saying that they wish to ascend to the mountain of $\mathrm{YHWH}$, where his temple represents his presence. The reason for going up to the 'house of $\mathrm{YHWH}^{\prime}$ is so that he can teach them how to live according to his 'ways'. Zion will be recognised in the international arena as a place of instruction and revelation of the word of Yahweh. By means of a parallelism, Zion is linked to Jerusalem and torah [law] to the word of Yahweh. From a position where Zion has lost her attraction for people and where revelation no longer takes place in 3:12, the opposite will take place in future: Zion and the temple mount will be attractive not only to the people of Israel and Judah, but to the nations of the world. It will be a place where YHWH is present, where teaching of 'his ways' take place and from where his word is revealed.

According to verse 3, Zion will be a place where international judicial matters will be settled. Whereas verse 1 mentioned 'peoples' and verse 2 'many nations', verse 3 refers to both. It is envisaged that many peoples and strong nations will benefit from Yahweh's arbitration in their disputes. However, there is still more to happen in Zion in future. Most surprisingly, the following is stated: warring parties would transform their offensive weaponry into agricultural tools (cf. Hillers 1984:51; J1 3:10). This is an indication of an era of construction because of the absence of the destruction which accompanies war. It will be a time of peace between nations that will no longer train for war (cf. also $1 \mathrm{Ki} \mathrm{4:25}$ and Zch 3:10 and related references in $2 \mathrm{Ki} \mathrm{18:31;} \mathrm{Is} \mathrm{36:16} \mathrm{and} \mathrm{J1} \mathrm{2:22).}$ What is expressed here is a sigh and longing for real peace and the absence of strife in the future.

Two images are employed in verse 4 to portray a sense of peace and tranquillity. Each person will sit under their own vine and fig tree. These two images point to an expected time of security, stability and prosperity in the future. Besides the images indicating peace, reference is made to ownership of property. The ideal of the restoration and possession of land underlying this image should not be overlooked (cf. chs 2 and 3). This oracle will come to pass because it is authenticated by YHWH Seba'ôt. Alfaro (1989:49) takes this as 'an emphatic affirmation of the preceding oracle or as a faith response of the community.' Mays (1976:98) calls it a 'concluding messenger formula'. The declaration in verse 5 that the people of YHWH will live in the name of their God has liturgical overtones. Whereas verse 1-4 communicated a future vision, verse 5 returns to the reality of the present, urging the people of Judah to worship YHWH here and now (McKane 1998:125-126; Allen 1976:327-328).

The oracle in verse 1-5 does not focus on Zion as a dominating power in world affairs, but rather on justice, true revelation and peace. In this regard it stands in stark contrast to chapter 2 and especially chapter 3 with its cry for justice, truth and peace, because of a leadership that misused its power and position.

\section{Theological solution for the juxtaposing of Micah 3:12 and 4:1}

Micah 3:12 brings the judgement oracle against the various leaders in Judah and Israel in 3:9-12 to a disastrous end. $\mathrm{YHWH}$ is portrayed as being at the end of his patience with his people. The political leaders have violated the covenant agreement by acting unjustly; the religious functionaries are false, speaking hollow words of peace to those who seek guidance; the judges take bribes and the priests teach for money. The leaders have no regard for people, but spill their blood to promote their own interests. Micah, as well as many of the other prophets in the Old Testament, portrays YHWH as one who punishes those who are disloyal to his covenant stipulations. Although known as one who reveals himself to his people through the prophets, it is said that he will no longer do it. There will be no visions, no guidance, no answering of his people if they call on him. Zion, the symbol of security and place of YHWH's presence, has lost its importance and significance. The theological portrayal of $\mathrm{YHWH}$ as a judging God is underscored by powerful metaphorical imagery: Zion will be like a ploughed field; Jerusalem will be like a heap of rubble and the temple hill will be like a mound overgrown with thickets. This is a picture of destruction and inaccessibility. YHWH's judgement entails that the very basis of their belief system and security is undermined. The royal Zion theology based on Zion, a king in the lineage of David and the temple as symbols of security and guarantee of YHWH's presence, is destabilised in the process.

In contrast to a God of judgement and destruction, Micah 4:1-5 depicts YHWH as a God of restoration and renewal. In time to come he will make a new beginning by elevating Zion to greater glory. YHWH will be at the heart of the new era. The once humiliated Zion with its temple mount will be elevated above the surrounding mountains. It will be a permanent solution and will be so attractive to the foreign nations that they will flock there to interact with YHWH. Not only is the temple hill restored, but it will be elevated to greater importance than before. It will gain universal status; it will soar above the mountains of other nations, implying that YHWH will surpass other gods in power and influence. 
The priests are not mentioned as the teachers in the future dispensation, but YHWH. Besides this he will again reveal his word as the norm for people to live by. However, the revelation of YHWH's word will have a wider impact, of significance to the pilgrims from other nations making their way to Zion. At the time when Micah acted as prophet, the Assyrians were a threat to Israel and Judah. According to Micah 4:1-5, however, wars will come to an end in future and peace will prevail amongst nations, all because of YHWH. In another sense, this oracle underscores the previous oracle of doom on Zion, because the better future is only to be expected after the realisation of disaster for Jerusalem expressed in the previous sections (Shaw 1993:101-102).

The view taken in the reasoning on Micah 4:1 was not to regard the time formula as referring to the end times, therefore as eschatological, but to a time to come. In future the position and conditions with regard to Zion will change for the better, because YHWH is also the God of salvation, the God of new beginnings. The salvation oracle therefore entails not only a regaining of what was lost by his people through judgement, but a focus on $\mathrm{YHWH}$, whose actions will affect the nations of the world (Rogerson 2009:40-41).

As mentioned before, some scholars simply regard salvation oracles as secondary and later additions. This is the easy way out and not satisfactory when the text is analysed for its theological meaning and purpose. The question is also asked whether a prophet of doom is capable of or interested in proclaiming salvation oracles to YHWH's people. There is no reason to restrict a prophet to doom and condemnation, because different situations require different kinds of oracles suited for that specific context. It would therefore be wrong to altogether deny the prophet Micah any oracle of salvation in the book of Micah.

The concern of this article is not so much to prove that all the oracles in the book of Micah originated from the prophet Micah. The aim is rather to present a reasonable and constructive proposal on how to make sense of the two very distinct views juxtaposed in the book. The placement of the two oracles under discussion (3:9-12 and 4:1-5) is most probably the work of redactor(s) of the Micah text. This view is substantiated by the research of De Vries (2003:256-257), who states that a time expression like the one in $4: 1$ is an indication of redactor activity. From research on the book of Micah as a whole, a structural pattern was observed according to which textual units of doom were followed by oracles of salvation (cf. Allen 1976:197-20). The section proclaiming doom in Micah 1:1-2:11 is followed by a salvation oracle in $2: 12-13$. The same pattern is followed in 3:1-12 (doom) followed by several salvation oracles in chapters 4 and 5 . We again have several doom oracles in 6:1-7:7, followed by a final section containing salvation oracles in 7:8-20. It seems that a deliberate effort was made to structure the collection of oracles dedicated to the prophet Micah according to the above-mentioned pattern. Using the two passages in 3:9-12 and 4:1-5 as a point of departure, the argument presented here is that the organisation of the book was not only done with a literary concern, but in particular with a theological concern. The view promoted here is that the literary structure has a theological aim and purpose. The final text of the book presents YHWH not only as a God of doom and judgement, but also as a God of new beginnings.

To say that $\mathrm{YHWH}$ is a God of judgement or a God of salvation is one thing. The nature and the consequences of his judgement are context-specific. Likewise, portraying him as a God of salvation is also context-specific. The rhetoric used is important to inform and portray how YHWH's judgement and salvation are actualised. The two Micah examples are pieces of the puzzle contributing to the bigger picture of how YHWH is portrayed in judgement and salvation.

\section{Brief excursion on the status of theological claims}

The issue that comes to mind is whether the observations that YHWH is a God of judgement and of salvation are ontological claims. For some scholars the answer to this question is quite obvious, namely that God reveals himself and that his revelation transcends the historical reality (cf. the lengthy discussion offered by Waltke 2007b:29-77). In contrast to this standpoint on revelation, inspiration and authority, Collins (2005:5-6) argues that we cannot make such claims, because they concern the metaphysical, which denies verification. To avoid the dilemma somewhat, Brueggemann (1997:6265, 2006:675-697) regards views derived of God from the Hebrew text as a 'testimony' of the people of Israel. Only by accepting such utterances as true do they become ontological in nature. I agree with Collins that we cannot determine the truth of utterances only from the biblical text itself, but that matters such as archaeology and other sources 'outside' the biblical text also play in on the status of 'truth' of claims.

An attractive way of looking at the issue at stake is Ricoeur's statement that we must first and foremost take cognisance of the various genres we encounter in biblical speech. He argues that we should consider the 'poetic function of language' which appeals to the imagination of people (Ricoeur 1980:75, $103,117)$. In terms of the discussion offered in this article, then, Micah as a prophetic text should be considered. The language used in 3:9-12 has the function of urging the people to imagine what destructive consequences their disobedience would have if $\mathrm{YHWH}$ acted in judgement. This is followed by 4:1-4, which again urges the people to imagine how YHWH will act in future to make a new beginning which will benefit the people of Israel and the nations. There is value in Collins's (2005) statement that:

assertions about God or the supernatural are most easily explained as rhetorical devices to motivate behaviour ... The biblical text must also be recognised as proposals about metaphysical truth, as attempts to explain the workings of reality. (p. 22)

The concept of testimony might have it limitations, but it is useful in the sense that it refers to the creative response of 'prophets' (scribes) to what they know about YHWH from tradition and their sensitivity to what is happening in history and in society. As people who understand themselves in 
terms of their relationship with $\mathrm{YHWH}$, of a calling to speak in service of $\mathrm{YHWH}$, they speak with conviction and with purpose. The testimony about YHWH is therefore an imaginative endeavour by humans (cf. Goldingay 2003:881882), from their experience of what they believe YHWH wants to communicate to either admonish or encourage his people.

What should be recognised, however, is that the context of the public arena in which the biblical text is read and its purpose will determine the value attributed to the text. In the academic arena with its critical, analytical and more sceptic approach to matters, the concern will not so much be on the authority of the text, but on its ideological nature and the socio-historical context in which it is embedded (Collins 2005:18-23). In the arena of the church and in the faith community, matters such as the authority, truth and faith relevance of the biblical text will concern people. What should be acknowledged is that all authority assigned to the biblical texts are derived authority (McDonald 2008:237). A practice that will benefit all stakeholders would be the critical interaction between the various arenas or spheres interested in the biblical text.

\section{Conclusion}

What theological purpose does it serve to place two seemingly contrasting oracles next to one another? It serves the purpose of showing that disobedience has farreaching and devastating consequences, but that it does not necessarily exclude the possibility of new and better things to come if YHWH takes centre stage. The theological message is that 3:12 is not the end; with $\mathrm{YHWH}$, a new and more significant beginning is possible. The following quotation from Rogerson (2010) seems appropriate:

The divine 'greatness' consists of the fact that it was able to absorb and outlast the obtuseness of the people freed from slavery; that the journey to the promised land was completed; that the destruction of Jerusalem and its temple was not the end of the story. The 'hot' histories have an 'openness' because the last word rests with God and not the human race. (p. 41)

This is precisely the conclusion to arrive at when the two text units discussed in this article are read together: YHWH has the last word, he determines the future.

The structural placement of oracles of doom and salvation next to each other is not unique to the book of Micah, but occurs in several other prophetic texts as well. What comes to mind is the salvation oracle in Amos 9:11-15 in a book consisting of mainly judgement oracles. Another example is Jeremiah 23:1-4, 5-6 and 7-8, that follow a cycle of judgement oracles aimed at the kings in the final days of Judah before the commencement of the Babylonian exile. Studying this phenomenon in other biblical texts from a literary and theological perspective would render interesting results.

Most of the approaches mentioned in this article contribute to new perspectives on the book of Micah. The fact that scholars keep on suggesting new ways of reading the book, is an indication that no approach will ever satisfy everybody. People have different interests and skills and are therefore naturally more attracted to a certain approach to prophetic texts. My observation of the text under discussion made me realise that it is possible to read each of these passages as separate units, taking the relevant contexts into account. It is possible to draw some theological conclusions from each of these passages. From a literary perspective, however, it seems that the perspective of the final version of the text also needs to be taken seriously. It is not possible to ignore the fact that an oracle of doom regarding Zion is placed next to an oracle of salvation also regarding Zion. The conclusion drawn in this article is that the two oracles were juxtaposed deliberately to serve a certain purpose. A theological solution should be considered, which communicates to the people of Israel and Judah that YHWH's judgement in this context is not the final word, but that a new beginning is possible. The Micah text testifies that the YHWH who acts in judgement is also the one who promises a new beginning. The focus shifts from people who, because of a false sense of security, thought they could disregard YHWH and determine their own future, to a focus on YHWH who determines the future and is willing to begin anew with not only his covenant people, but also the nations.

\section{Acknowledgements}

This article is dedicated to Professor J.A. Loader, a true scholar to be admired.

\section{Competing interests}

The author declares that he has no financial or personal relationship(s) which may have inappropriately influenced him in writing this article.

\section{References}

Alfaro, J.I., 1989, Micah: Justice and loyalty, Eerdmans, Grand Rapids, MI. PMCid:PMC286656

Allen, L.C., 1976, The books of Joel, Obadiah, Jonah and Micah, Eerdmans, Grand Rapids, MI.

Anderson, F.I. \& Freedman, N., 2000, Micah, Doubleday, New York, NY.

Brueggemann, W., 1994, A social reading of the Old Testament, P.D. Miller (ed.), Fortress, Minneapolis, MN.

Brueggemann, W., 1997, Theology of the Old Testament: Testimony, dispute, advocacy, Fortress, Minneapolis, MN.

Brueggemann, W., 2003, An introduction to the Old Testament: The canon and Christian imagination, Westminster John Knox, Louisville, KY.

Brueggemann, W., 2006, 'Old Testament theology', in J.W. Rogerson \& J.M. Lieu (eds.), The Oxford handbook of Biblical studies pp. 675-697, Oxford University Press, Oxford, UK.

Collins, J.J., 2005, Encounters with Biblical theology, Fortress Press, Minneapolis, MN.

Cuffey, K.H., 1987, 'The coherence of Micah: A review of proposals and a new interpretation', DPhil dissertation, Drew University.

De Vries, S.J., 2003, 'Futurism in preexilic Minor Prophets compared with that of postexilic Minor Prophets', in P.L. Reditt \& A. Schart (eds.), Thematic threads in the Book of the Twelve, pp. 252-257, Walter de Gruyter, Berlin.

Goldingay, J., 2003, Old Testament theology: Israel's Gospel, InterVarsity Press, Downers Grove, IL.

Grabbe, L.L., 1995, Priests, prophets, diviners, sages: A socio-historical study of religious specialists in ancient Israel, Trinity Press International, Valley Forge, PA.

Hagstrom, D.G., 1988, The coherence of the Book of Micah, Scholars Press, Atlanta, GA. PMCid:PMC202673

Hillers, D.R., 1984, Micah, Fortress Press, Philadelphia, PA. PMCid:PMC481636 
Jacobs, M.R., 2001, The conceptual coherence of the book of Micah, Sheffield Academic Press, Sheffield.

Jacobs, M.R., 2006, 'Bridging the times: Trends in Micah studies since 1985', Currents in Biblical Research 4(3), 293-329. http://dx.doi.org/10.1177/1476993X06064627

Keel, O., 1978, The symbolism of the Biblical world: Ancient Near Eastern iconography and the book of Psalms, Seabury Press, New York, NY.

Mason, R., 1991, Micah, Nahum, Obadiah, Sheffield Academic Press, Sheffield.

Mays, J.L., 1976, Micah, SCM Press, London.

McDonald, L.M., 2008, 'Wherein lies authority? A discussion of books, texts, and translations', in C.A. Evans \& E. Tov (eds.), Exploring the origins of the Bible: Canon formation in historical, literary, and theological perspective, pp. 203-239, Baker Academic, Grand Rapids, MI.

McKane, W., 1998, Micah: An introduction and commentary, T\&T Clark, Edinburgh. PMCid:PMC2448694

Ricoeur, P., 1980, Essays on Biblical interpretation, Fortress Press, Philadelphia, PA.

Rogerson, J.W., 2009, 'The Israelite city: Biblical perspectives', in J.W. Rogerson \& J. Vincent (eds.), The city in Biblical perspective, pp. 21-41, Equinox, London.
Rogerson, J.W., 2010, A theology of the Old Testament: Cultural memory, communication, and being human, Fortress, Minneapolis, MN.

Shaw, C.S., 1993, The speeches of Micah, JSOT Press, Sheffield.

Troxel, R.L., 2012, Prophetic literature: From oracles to books, Wiley-Blackwell, Chichester, West Sussex, UK.

Van der Woude, A.S., 1976, Micha, G.F. Callenbach, Nijkerk. PMid:980126

Wagenaar, J.A., 2001, Judgement and salvation: The composition and redaction of Micah 2-5, Brill, Leiden.

Waltke, B.K., 1988, Obadiah, Jonah and Micah, InterVarsity Press, Downers Grove, IL. PMid:11649259

Waltke, B.K., 2007a, A commentary on Micah, Eerdmans, Grand Rapids, MI.

Waltke, B.K., 2007b, An Old Testament theology: An exegetical, canonical, and thematic approach, Zondervan, Grand Rapids, MI.

Wessels, W.J., 2009, 'Empowered by the Spirit of Yahweh: A study of Micah 3:8', Journal of Biblical and Pneumatological Research 1, 33-47.

Wildberger, C.H., 1972, Jesaja, Neukirchener Verlag, Neukirchen-Vluyn.

Wolff, H.W., 1990, Micah: A Commentary, transl. G. Stansell, Augsburg, Minneapolis, MN. 